\title{
Influential Host Factors to the Incidence of HIV/AIDS in Key Populations in Pati District
}

\author{
Faktor Host yang Berpengaruh terhadap Kejadian HIV/AIDS pada Populasi \\ Kunci di Kabupaten Pati
}

\author{
Dwi Murtono*, Puguh Riyanto**, Zahroh Shaluhiyah****
}

\begin{abstract}
*School of Postgraduated of Diponegoro University, Semarang, Indonesia, **Faculty of Medicine, Diponegoro University/Central General Hospital of Dr. Kariadi, Semarang, Indonesia, ***Faculty of Public Health, Dipenogoro University, Semarang, Indonesia
\end{abstract}

\begin{abstract}
Human Immunodeficiency Virus (HIV) and Acquired Immune Deficiency Syndrome (AIDS) are serious diseases in the world in which one of transmission methods is through sexual intercourse. This study aimed to explain the influential host factors to the incidence of HIVIAIDS in key populations. The study was conducted in March-September 2016. The study was observational analytic with case-control design in key populations in Pati District. Cases were 53 patients living with HIVIAIDS, while controls were 53 patients not living with HIVIAIDS. The sampling technique employed was consecutive sampling. Data were obtained from medical records and interview questionaire. This study applied chi-square test to analyze bivariate data, and multiple logistic regression to analyze multivariate data. Results indicated that the influential factors to the incidence of HIVIAIDS in key populations were inconsistent condom use behavior, records of suffering from sexually-transmitted infections (STIs), and forms of sexual activity. While, factors which were not influwntial to the incidence of HIVIAIDS were multiple sex partner behavior, sex accessory use behavior, tattoo needle use behavior, injecting drug use behavior. In conclusion, several influential factors to the incidence of HIVIAIDS in key populations are the inconsistent condom use behavior, records of suffering from STIs, and forms of sexual activity.
\end{abstract}

Keywords: HIVIAIDS, host factors, key population

\begin{abstract}
Abstrak
Human Immunodeficiency Virus (HIV) dan Acquired Immune Deficiency Syndrome (AIDS) merupakan penyakit berbahaya di dunia yang salah satu metode penularannya adalah melalui hubungan seksual. Penelitian ini bertujuan menjelaskan faktor-faktor yang berpengaruh terhadap kejadian HIVIAIDS pada populasi kunci. Penelitian dilakukan dari bulan Maret sampai September 2016. Penelitian analitik observasional dengan rancangan kasus kontrol pada populasi kunci di Kabupaten Pati. Kasus sebanyak 53 pasien positif HIVIAIDS, sedangkan kontrol sebanyak 53 pasien negatif HIVIAIDS.Pengambilan sampel menggunakan teknik consecutive sampling. Data diperoleh dari riwayat medis dan wawancara kuesioner. Penelitian ini menggunakan uji kai kuadrat pada analisis bivariat dan regresi logistik ganda pada analisis multivariat. Hasil penelitian menunjukkan bahwa faktor yang berpengaruh terhadap kejadian HIVIAIDS pada populasi kunci dalam penelitian ini adalah perilaku pemakaian kondom, riwayat menderita infeksi menular seksual, dan bentuk aktifitas seks kombinasi. Faktor yang tidak berpengaruh adalah perilaku multi pasangan seks, perilaku penggunaan aksesoris seks, perilaku penggunaan jarum tato, dan perilaku penggunaan narkoba suntik. Sebagai kesimpulan, faktor yang berpengaruh terhadap kejadian HIVIAIDS yaitu perilaku pemakaian kondom yang tidak konsisten, riwayat menderita IMS dan bentuk aktivitas seks kombinasi.
\end{abstract}

Kata kunci: HIVIAIDS, faktor host, populasi kunci

How to Cite: Murtono D, Riyanto P, Shaluhiyah Z. Influential host factors to the incidence of HIVIAIDS in key populations in Pati District. Kesmas: National Public Health Journal. 2018; 13 (1): 17-22. (doi:10.21109/kesmas. v13i1.1463)
Correspondence: Dwi Murtono, School of Postgraduated of Dipenogoro University, Imam Bardjo Street No.5 Semarang 50241, Phone: +6224-8318856, E-mail:dwi_murt@yahoo.com

Received: March 20th 2017

Revised: September 07th 2017

Accepted: October $12^{\text {th }} 2017$ 


\section{Introduction}

The development of sexually-transmitted diseases (STDs) issues, including Human Immunodeficiency Virus (HIV) and Acquired Immune Deficiency Syndrome (AIDS) increases both quantitatively and qualitatively. In the last 20 years, the number of patients reached more than 60 million people and about 20 million of them died. Not surprisingly, the problem of HIV and AIDS has become an epidemic in almost 190 countries. ${ }^{1}$

HIV and AIDS are dangerous diseases in the world that one of transmission methods is through sexual intercourse. ${ }^{2,3}$ HIV/AIDS is a global case that resembles an iceberg phenomenon. Cases that occur in each year are always experiencing fluctuations that are not significant and unpredictable. ${ }^{4}$

Based on the distribution in Indonesia, Central Java Province is not the highest in the incidence of HIV/AIDS in Indonesia. Central Java Province until March 2015 ranked the sixth with 10,530 HIV cases and 4,086 AIDS cases. ${ }^{5}$ The increasing number of people with new HIV infections in Central Java shows a significant rate and becomes one of the highests in Indonesia. Based on Basic Health Research in 2014, the number of new HIV infection cases in Central Java in 2013 is 2,322 cases or increase by $109.19 \%$ from the number in 2012 . The Health Profile of Central Java Province in 2014 indicates that HIV/AIDS cases are found across all districts/cities in Central Java. ${ }^{6}$

The development of HIV/AIDS in Indonesia is getting out of control, including one in Pati District which ranks the fourth in Central Java Province until the end of May 2016 in new HIV/AIDS cases found after Semarang, Surakarta and Banyumas District. ${ }^{7}$ Pati District Health Office reported the prevalence of incidence of HIV/AIDS at 914 cases until May 2016.7 Based on these data, if compared to the previous year (2015), an increase in the case is as many as 56 cases (861 cases in 2015). While if compared to in 2014, there is an increase of 148 cases (715 cases in 2014). 8

The case of HIV/AIDS is initially found in homosexual groups, and now the case spreads to everyone without exception to be potentially infected with the HIV virus. The risk of transmission appears not only in high-risk populations. Existing data indicate that HIV/AIDS has infected housewives, even children or infants who are conceived or infected from HIV-infected women. Nevertheless, trends show that the highest HIV/AIDS cases are found from sexual contact, transmitted from and transmitted to sex workers. In the last few years, the increasing cases of AIDS are more generally found in drug users, specifically injecting drug users. ${ }^{9}$

The distribution of HIV is still concentrated in key populations. There are female sex workers directly or indirectly, male sex men, sex workers, transvestites and in- jecting drug users. ${ }^{10}$ This is in line with the distribution of HIV/AIDS based on the rate of risk factors and extent of the HIV epidemic in Pati District that mentions the highest group on the clients of sex workers as many as 303 cases, female sex workers with 205 cases, high risk couples with 176 cases, homosexual with 21 cases and injecting drug users with 5 cases. 8,11

There was no information on key population's characteristics and the influential host factors to the HIV/AIDS infection cases in key populations in Pati District, so then this study was carried out on these issues. The aim of the study was to explain several influential host factors to the incidence of HIV/AIDS in key populations in Pati District.

\section{Method}

This study used quantitative observational analytic approach with case control design. ${ }^{12}$ The study took place in Pati District, Central Java Province, which was carried out for two months and started from March to September 2016. The study samples were female sex workers both directly and indirectly, male sex men, the clients of sex workers, transvestites and injecting drug users who had taken HIV test, based on VCT's clinical data of RAA Soewondo Hospital of Pati, Kayen Public Hospital, and Pulmonary Health Center of Pati. The total of sample was 106 samples consisting of 53 cases and 53 controls.

Sampling technique in this study was determined by the consecutive sampling technique. Case sample was determined first, then followed by determination of control sample by the same way of determining the case samples. The data used came from VCT clinic at RAA Soewondo Pati Public Hospital, Kayen Pati Public Hospital and Pati's Pulmonary Health Center. The inclusion criteria for the case sample was the HIV/AIDS-positive key populations who were willing to be the samples of study by signing informed consent, while the exclusion criteria was the HIV/AIDS-positive key populations who were absent at the time of study. Then the inclusion criteria for control sample was the HIV/AIDS-negative key populations who were willing to be the samples of study by signing informed consent. The control respondents were adjusted to the risk group in the case respondents. While the exclusion criteria was the HIV/AIDS-negative key populations who were absent at the time of study. In this study, matching was done to sex and risk group variable.

The study variables consist of dependent variable that was the incidence of HIV/AIDS in key populations, and the independent variables that were the behavior of condom use, multiple sex partner behavior, records of sexually-transmitted infections, the form of sexual activity, sex accessory use behavior, tattoo needle use behavior, and injecting drug use behavior. Data collection technique was through questionnaire-based interview results 
from respondents.

Data analysis phase was univariate analysis to describe dependent variable and independent variables $\mathrm{u}$ sing frequency distribution table; bivariate analysis using simple logistic regression to regress a dependent variable on each independent variable, and to analyze the risk (odds ratio) of exposure to case at 95\% confidence level with $2 \times 2$ table; multivariate analysis using multiple logistic regression to regress dependent variable on several independent variables.

Informed consent was obtained from all the key populations included in the study that were willing to be respondents. Ethical clearance in this study have been obtained from Health Ethics Committee of Faculty of Medicine, Diponegoro University and Dr. Kariadi Semarang Central General Hospital.

\section{Results}

At both the case group and the control group, generally, most respondents were at the age of between 24-45 years $(63.2 \%)$, female $(52.8 \%)$, sex workers $(63.2 \%)$, married $(52.8 \%)$, graduated from primary school $(34.9 \%)$, working outside the city $(52.8 \%)$.

The bivariate analysis showed that the influential factors to the incidence of HIV/AIDS in key populations were inconsistent condom use behavior, records of suffering from STIs, combination forms of sexual activity, partners' records of STIs, and the partner's records of HIV/AIDS. The complete bivariate analysis results are presented in Table 1. Multivariate analysis found that the influential variables to the incidence of HIV/AIDS in key population's behavior were inconsistent condom use behavior, records of suffering from STIs, and combination forms of sexual activity. The complete multivariate analysis results are presented in Table 2 .

\section{Discussion}

Multivariate analysis found that the key population with the inconsistent condom use behavior had 5.34 times risk of HIV/AIDS compared to key populations with the consistent condom use ( $\mathrm{p}$ value $=0.028 ; 95 \%$ $\mathrm{CI}=1.19-23.82$ ). The results of this study are in line with study by Maria Amelia Guteres, 12 in Timor Leste stating that the consistency of condom use is a risk factor of HIV/AIDS with OR $=3.308$ ( $\mathrm{p}$ value $=0.002 ; 95 \%$ $\mathrm{CI}=1.47-7.45)$.

Condoms have been widely recommended to prevent STDs and have been shown to effectively lower infection rates in both men and women. Although not completely, condoms effectively reduce HIV transmission, genital herpes, genital warts, syphilis, gonorrhoeae, chlamydia and other infections. In accordance with a 2000 case report from the National Institutes of Health, the use of condoms correctly and consistently reduces HIV transmission by up to $85 \%$. The main reason that condoms sometimes fail to prevent transmission of HIV/AIDS infection is the improper and inconsistent use, not because of the condom factor itself. 13

Table 1. Results of Bivariate Variable Analysis against the Incidence HIV/AIDS in the Key Populations

\begin{tabular}{lcccc}
\hline \multirow{2}{*}{ Variable } & p Value & OR & \multicolumn{2}{c}{$\mathbf{9 5 \%}$ CI } \\
\cline { 5 - 6 } & & & Lower Bound & Upper Bound \\
\hline Inconsistent condom use behavior & 0.001 & 7.87 & 2.14 & 28.87 \\
Multiple sex partner behavior & 0.066 & 3.40 & 0.86 & 13.38 \\
Records of suffering from STIs & 0.000 & 4.45 & 1.92 & 10.34 \\
Combination forms of sexual activity & 0.000 & 4.89 & 2.15 & 11.14 \\
Sex accessory use behavior & 0.301 & 1.72 & 0.61 & 4.84 \\
Tattoo needle use behavior & 0.447 & 1.47 & 0.54 & 4.01 \\
Injecting drug use behavior & 0.558 & 2.03 & 0.17 & 23.19 \\
The number of sex partners & 0.229 & 1.62 & 0.73 & 3.58 \\
Records of STIs in partners & 0022 & 4.36 & 1.14 & 16.68 \\
Records of HIV/AIDS in partners & 0.030 & 3.58 & 1.07 & 11.97 \\
\hline
\end{tabular}

Notes:

$\mathrm{OR}=$ Odds Ratio, $\mathrm{CI}=$ Confidence Interval, $\mathrm{STI}=$ Sexually-Transmitted Infection

Table 2. Results of Multiple Logistic Regression Test on Influential Risk Factors to the Incidence of HIV/AIDS

\begin{tabular}{lcccr}
\hline Variable & $\beta$ & $\mathbf{p ~ V a l u e}$ & Exp $(\beta) / \mathbf{O R}$ & \multicolumn{1}{c}{$\mathbf{9 5 \%} \mathbf{C I}$} \\
\hline Condom use behavior & 1.68 & $0.028^{*}$ & 5.34 & $1.19-23.82$ \\
Records of suffering from STIs & 1.07 & $0.027^{*}$ & 2.93 & $1.13-7.57$ \\
Form of sexual activity & 1.46 & $0.002^{*}$ & 4.32 & $1.74-10.75$ \\
Constant & -2.78 & & & \\
\hline
\end{tabular}

Notes:

*p value $<0.05, \mathrm{OR}=$ Odds Ratio, $\mathrm{CI}=$ Confidence Interval 
Study by Riska Ovany, ${ }^{14}$ in Semarang showed that several factors influencing condom use were the low condom offering capacity $(\mathrm{OR}=26.63)$, fixed customer (16.68), and no customer support (7.4). While the study by Irwan Budiono, 15 in Argorejo Semarang relocation showed that the consistency of condom use was only at $62.9 \%$, then the consistency of condom use was influenced by knowledge, attitude, access to information on STIs and HIV, customer's perception, and support of pimp.

The field study obtained information that the respondents had difficulty in making request to wear a condom. Respondents basically understood the risk of HIV/AIDS and STIs if not using condoms consistently. The fear of not getting paid for sexual transactions made the bargaining power of sex workers weaker.

In Kismiyati et al., 16 the study concluded that all informants (sex workers in Tanjung Elmo District, Papua) strongly agree on the use of condoms during sexual activity, but this good attitude does not guarantee the consistency in the use of condoms because of the violence by the alcohol-affected customers, financial factors, factors of trust and feelings and fraud from customers. There is still a small proportion of sex workers who do not use condoms during sexual intercourse that is on boyfriends and expensive paying customers who are still trapped in the myths surrounding STIs.

In this study, most respondents (67 people) worked as sex workers either in the women sex workers, MSM and transvestites. The low-income customers were looking for low-cost sex workers. The low-cost sex workers were commonly found on the roadside or street localization. Localization around Jatiwangi Juwana, Botonan Trangkil and Wage Market Margorejo were in bushes and rice fields with minimal lighting and minimal clean water, so that sex workers and customers would override the use of condoms properly and correctly. Street localization has a high risk of HIV transmission because it does not pay attention to the level of hygiene, condom safety, and the low use of condom. This is in accordance with study by Widyastuti, 17 that condom use behavior in street women sex workers in East Jakarta showed that more than half of respondents $(60.7 \%)$ used condoms during their last sex with their partners. However, the consistency of condom use has not been maintained, the use in the last week was $27.7 \%$ and on the last working day at $46.4 \%$.

The next result of multivariate analysis stated that the key population with STIs records had 2.92 times risk of HIV/AIDS compared to the key populations that did not have. The results of this study are in line with the study by Susilowati, 18 finding that the records of STIs affect the incidence of HIV/AIDS with OR 2.676 ( $\mathrm{p}$ value = $0.011 ; 95 \% \mathrm{CI}=1.25-5.72$ ).
STIs require early observation/detection because the STIs are one of the doors to facilitate the HIV transmission. ${ }^{18}$ STIs are thought to increase the incidence of HIV and AIDS because living with STIs can lead to normal epithelial defect disorders. ${ }^{19}$

STIs are various infections that can be transmitted from one person to another through sexual contact. STIs are more at risk when having sexual intercourse by alternating partners either through vagina, oral or anal. STIs that are popular in Indonesia include gonorrhea and syphilis. One of the STIs that cannot be cured is HIV/AIDS. The spread of HIV/AIDS occurs due to freesex behavior, the decline of religious values, lifestyle, occupation, and failure to foster households. ${ }^{20.21}$

Most people are unaware of the early symptoms of STIs, especially among key populations, so then routine and comprehensive screening of key members of the population is necessary. The implementation of mobile STIs screening that has been running in Pati District is only available at two primary health cares, namely Margorejo Primary Health Care and Batangan Primary Health Care. Both primary health cares have not been able to reach all the key populations in Pati District due to limited manpower and cost allocation reasons.

Based on study by Aridawarni, 22 several factors that influence the increase of STIs include age, education lev$\mathrm{el}$, the number of customers, and the long working period as women sex worker. Age is closely related to the liveliness of one's sexual behavior. The younger age will easily get customers in commercial sex, hence at risk of contracting STIs and HIV/AIDS. ${ }^{22}$ In addition, the study results by Budiman et al., 23 mentioned that education also affects the incidence of STIs. Statistical test results obtained that there is correlation between knowledge of the street women sex worker and the street women sex worker praxis in efforts of STIs and HIV/AIDS prevention with chi-square test $(\alpha=0.05$, $p$ value $=0.032)$.

Jasan et al. study in Aridawarni,22 mentioned that the long working period as a sex workers is also an important factor in the incidence of STIs, because the longer the working days of a women sex worker, the more likely she has got to serve customers who have HIV. Similarly, if the number of costumers increases, it will increase the possibility of contracting HIV. Conversely, if the female sex workers have been infected with STIs, then more and more customers may be infected from them.

Furthermore, multivariate analysis results indicated that the key population with combined sexual activity had 4.32 times risk of HIV/AIDS compared to sexual activity without combinations (only oral, anal or vaginal course only). Study by Aryani et al., ${ }^{24}$ mentioned that STI is one cause of HIV/AIDS disease, which is riskier if having sexual intercourse with multiple partners, either through vagina, oral or anal. 
Sexual activity is generally done through vaginal, anal and oral penetration. Intercourse through the anus is considered the riskiest sex practice. Lack of lubrication in the type of anal intercourse can cause blisters on the penis and mucosa rectum, hence easily transmit the virus. In study by Suwandani, ${ }^{25}$ it was mentioned that anal sexhad a risk of injury to the anus (because the anus is not elastic), so by an anal lesion, if the sex partner was exposed to STIs and HIV, it will be more easily transmitted.

The results of study in the field obtained information that respondents working as sex worker, both female sex workers and transgender, will do anything for the money, including sex combination. Based on interviews, the women sex workers' customers and transvestites susceptible to sex combinations were young customers under the age of 30 years who were still curious about sex. Customers of sex workers would try a variety of sexual forms due to a sense of curiosity and want to get more pleasure than the usual sex. In the study by Ninik et al., 26 in 2012, the usual sexual activity performed put the study subjects (female sex worker) at risk of contracting/transmitting the STIs. All the subjects of the study used to serve consumers to have sex by inserting the genitals into the vagina (vaginal), but some others also added that in addition to vaginal, consumers usually also asked for oral sex (inserting the genitals in the mouth), and anal insert the genitals to the rectum). Sexual activity such as vaginal, oral and anal sex is a type of sexual contact that can be at risk of transmitting the STIs, especially if it is not done safely like not using condoms. ${ }^{26}$

Risk groups of men who have sex with men (MSM) also play a role in the spread of HIV/AIDS in Indonesia. HIV prevention for MSM is very difficult due to the high risk of their biological activity through anal and oral sex, frequency and variety of sexual activity. ${ }^{27}$ MSM also plays a role in the transmission of women because some MSM also have sexual intercourse with women, thus contributing to the bridge connecting HIV virus to a wider population. ${ }^{28}$

\section{Conclusion}

Several influential factors to the incidence of HIV/AIDS in key populations are the inconsistent condom use behavior, records of suffering from STIs, and forms of sexual activity. While, several factors that do not influential to the incidence of HIV/AIDS in key populations are multiple sex partner behavior, sex accessory use behavior, the tattoo needle use behavior, injecting drug use behavior, records of STIs in partners, and records of HIV/AIDS in the partner.

\section{Recommendation}

The study results suggest community, especially risky sex offenders to consistently and correctly use a condom during risky sexual intercourse; offenders to seek for treatment immediately if early symptoms of STIs are found in themselves and among those closest, as the injury from STIs can be the entrance of HIV/AIDS; and offenders to avoid combined forms of sexual activity (vaginal, anal, oral sex at the same time) in key populations.

The next recommendation is that the related institution should improve information, education and communication about the influential factors to the incidence of HIV/AIDS in key populations by counseling and poster assistance or leaflet easily to be accessed; create specific policies regarding the existence of street localization, such as creating new localization that make sex workers and clients feel comfortable wearing a condom, or the localization is removed; routinely and thoroughly do screening of STIs and HIV/AIDS in key populations for the reduction of STIs and HIV/AIDS cases as early as possible; add the number of primary health care, human resources, and budget in order to carry out comprehensively and routinely mobile STIs screening on the key populations.

Recommendation is also given to other researchers to take a further study on the incidence of HIV/AIDS in key populations using different study designs, such as cohort to find out the earliest appearance of the incidence of HIV/AIDS in key populations.

\section{References}

1. Purnamawati. Perilaku pencegahan penyakit menular seksual di kalangan wanita pekerja seksual langsung. Kesmas: National Public Health Journal. 2013; 7 (11): 514-21.

2. Locke T, Keat S, Waker A, Mackinnon R. Microbiology and infectious diseases on the move. PT Indeks. 2013; 144-53.

3. Djoerban Z, Djauzi S. Textbook of medicine. The sixth edition of Volume 1. Jakarta : Internal Publising. 2014; 803-91.

4. Rachmawati TU, Widagdo L, Istiarti VGT. Faktor-faktor yang berhubungan dengan praktik seks berisiko penularan HIV/AIDS pada ibu rumah tangga (Studi kasus di wilayah kerja puskesams Bandarharjo, Kecamatan Semarang Utara). Jurnal Kesehatan Masyarakat. 2016; 4 (3): 1104-13.

5. Direktorat Jenderal Pengendalian Penyakit dan Penyehatan Lingkungan Kementerian Kesehatan Republik Indonesia. Laporan statistik kasus HIV/AIDS di Indonesia sampai dengan September 2014. Jakarta: Direktorat Jenderal Pengendalian Penyakit dan Penyehatan Lingkungan Kementerian Kesehatan Republik Indonesia; 2014 [cited 2015 may 22nd]. Available from: http://spiritia.or.id/Stats/starCurr.xls.

6. Komisi Penanggulangan HIV/AIDS Provinsi Jawa Tengah. Kondisi HIV \& AIDS di Jawa Tengah 1993 s/d 30 Juni 2014. Semarang: Komisi Penanggulangan HIV/AIDS Provinsi Jawa Tengah; 2014 [cited 2015 March 4th]. Available from: http://www.aidsjateng.or.id.

7. Dinas Kesehatan Provinsi Jawa Tengah. Laporan surveilans HIV/AIDS Mei 2016. Semarang: Dinas Kesehatan Provinsi Jawa Tengah; 2015.

8. Dinas Kesehatan Kabupaten Pati. Laporan surveilans HIV/AIDS in Mei 
2016. Pati: Dinas Kesehatan Kabupaten Pati; 2016.

9. Purwaningsih SS, Widyatun. Perkembangan HIV dan AIDS di Indonesia. Jurnal Kependudukan Indonesia. 2008. 3 (2) : 75-95.

10. Das P, Harton R. Bringing sex workers to the centre of HIV response. The Lancet. 2015; 385 (9962) : 3-4.

11. Kelompok Dukungan Sebaya Rumah Matahari. Analisis situasi ODHA di Kabupaten Pati. Pati: Kelompok Dukungan Sebaya Rumah Matahari; 2015.

12. Guterres MADO. Beberapa faktor risiko yang berpengaruh terhadap kejadian HIV/AIDS pada laki-laki umur 25-44 tahun (studi kasus di Kota Dili, Timor Leste) [Thesis]. Semarang : Diponegoro University. 2015.

13. Jatmiko AC, Martodihardjo S, Dewi, DK. Peranan kondom pada penderita HIV (The Role of Condoms in HIV Infection). Berkala Ilmu Kesehatan Kulit dan Kelamin. 2010; 22 (1): 45-48.

14. Ovany R. Beberapa faktor yang berpengaruh terhadap kepatuhan penggunaan kondom pada ODHA pekerja seks komersial [thesis]. Semarang: Program Studi Magister Epidemiologi Program Pascasarjana Universitas Diponegoro; 2014.

15. Budiono I. Konsistensi penggunaan kondom oleh wanita pekerja seks dan pelanggannya. Jurnal Kesehatan Masyarakat. 2012; 7 (2): 90-6.

16. Kismiyati, Syafar M, Natsir S. Perilaku penggunaan kondom terhadap pencegahan HIV dan AIDS pada pekerja seksual di Tanjung Elmo Kabupaten Jayapura [Thesis]. Makasar: Health Promotion Faculty of Public Health Hasanuddin University; 2014.

17. Widyastuti. Perilaku penggunaan kondom pada wanita penjaja seks jalanan di Jakarta Timur tahun 2006. Kesmas: National Public Health Journal. 2007; 1(4): 161-7.

18. Susilowati T. Faktor-faktor risiko yang berpengaruh terhadap kejadian HIV dan AIDS di Semarang dan sekitarnya. Jurnal Komunikasi Kesehatan. 2011; 2 (1): 1-16.

19. Pratiwi NL, Basuki. Analisis hubungan pengetahuan pencegahan HIV/AIDS dan perilaku seks tidak aman pada remaja usia 15-24 tahun di Indonesia. Buletin Penelitian Sistem Kesehatan. 2011; 14 (2): 192 202.

20. Kamila N, Siwiendrayanti A. Persepsi orang dengan HIV dan AIDS terhadap peran kelompok dukungan sebaya. Jurnal Kesehatan Masyarakat. 2010; 6 (1): 36-43.

21. Rokhmah D. Implikasi mobilitas penduduk dan gaya hidup seksual terhadap penularan HIV/AIDS. Jurnal Kesehatan Masyarakat. 2014; 9 (2): 183-90.

22. Aridawarni Y. Analisis determinan wanita pekerja seksual dengan kejadian infeksi menular seksual. Jurnal Obstretika Scientia. 2014; 2 (1): 123-45.

23. Budiman NA, Istiarti T, Syamsulhuda BM. Faktor-faktor yang berhubungan dengan praktik wanita pekerja seks (WPS) jalanan dalam upaya pencegahan IMS dan HIV/AIDS di sekitar alun-alun dan Candi Prambanan Kabupaten Klaten. Jurnal Promosi Kesehatan Indonesia. 2008; 3 (2): 120-26.

24. Aryani D, Mardianan, Ningrum DNA. Perilaku pencegahan infeksi menular seksual pada wanita pekerja seksual Kabupaten Tegal. Jurnal Kesehatan Masyarakat. 2015. 10 (2) : 160-8.

25. Suwandani R. Pengetahuan dan sikap berisiko waria dengan kejadian infeksi menular seksual (IMS) pada waria di Sidoarjo. Jurnal Berkala Epidemiologi. 2015; 3 (1) : 35-44.

26. Ninik, Nugraha PP, Riyanti E. Perilaku wanita pekerja seks dalam pencegahan infeksi menular seksual (studi kualitatif pada anak asuh di Lokalisasi Gembol, Sukosari, Bawen, Kabupaten Semarang. Media Kesehatan Masyarakat Indonesia. 2012; 11 (1): 71-4.

27. Sullivan PS, Carballo-Diéguez A, Coates T, Goodreau SM, McGowan I, Sanders EJ, et al. Successes and challenges of HIV prevention in men who sex with men. The Lancet. 2012; 380 (9839): 388-99.

28. Demartoto A, Gerilyawati IESE, Sudibyo DP. Risk-based sexuality: a case study in male sex-related men in Surakarta. Surakarta: Conference Indonesian Sociology Association; 2013. 